\title{
Ideology trumps evidence with new voluntary survey
}

Previously published at www.cmaj.ca

$\mathrm{O}$ n June 26, citing privacy concerns, Cabinet announced that one in five Canadians would no longer be required to complete the long version of Canada's census. Instead, it proposes that a new voluntary National Household Survey be sent to $30 \%$ of households. ${ }^{\prime} C M A J$ is lending its voice to the chorus of complaints over this change.

With no consultation, the Harper government has undermined evidence-based decision-making in Canada. For a government that made accountability a key priority, this policy choice is perplexing.

Information from the long-form census frequently guides program planning and evaluation for federal departments as well as other levels of government. In health care, it is an essential tool in the planning and delivery of services. It provides accurate and reliable data on social trends and issues, including the determinants of health, such as the relationships among income, gender, education, region, work and other factors that influence access to care and health outcomes. In fact, the long-form census is the only source that brings all these variables together and enables researchers to investigate new ways of understanding the determinants of health.

The census information allows us to relate the health and well-being of populations, even down to neighbourhoods. Without it, regional institutions will lose the only accurate information about the populations they serve.

The census's reliability and accuracy has ensured its widespread use as a research and evaluation tool. ${ }^{2}$ A search through the National Library of Medicine's database using the term "Canadian census" retrieved 7060 articles that examined the relationship between demographic characteristics of our population and the health and well-being of Canadians.

Information from the long-form census has been integral to numerous studies that have shaped our view on how new and emerging health challenges may be related to place of residence, socio-economic status and ethnicity. Without this information, Canada is stripped of an important resource to guide social interventions and investments to improve the health and well-being of Canadians.

The introduction of a new voluntary approach to collecting detailed information will make evaluations over time impossible - and unacceptable as a research tool. Changes from previous censuses will not be sufficiently reliable to be trusted by government, businesses or others, let alone peer-reviewed journals.

With so much at stake, why would the Harper government jeopardize such an important federal program? Minister of Industry Tony Clement indicated that cabinet was concerned about privacy and the intrusiveness of government. However, he did not produce letters of complaint or evidence of public outcry about intrusiveness.

What about privacy concerns? Again, no evidence was provided. To the contrary, Statistics Canada must abide by strict privacy laws and regulations. Only Statistics Canada has access to personal data, which are the only government data exempt from access by the Canadian Security Intelligence Service. In fact, it is enshrined in the CSIS Act. ${ }^{3}$ With these protections in place, there has never been a serious breach of privacy.
Some might argue that filling out the long form is timeconsuming. Given the benefits, it does not seem much to ask Canadians to spare an estimated one hour of each household's time every 25 years.

The Harper government has indicated that Statistics Canada will increase the random sampling from $20 \%$ to $30 \%$ at an estimated additional cost of $\$ 30$ million. However, uneven response rates will fatally undermine the quality of the data collected. ${ }^{4}$ With a voluntary survey, Aboriginal communities, poorer neighbourhoods, new immigrants and very wealthy households will have lower response rates than those for middle-class Canadians. This means that some communities will be under-represented or hardly represented at all. Adding more survey respondents will only result in a larger amount of biased, largely unusable data.

Statistics Canada may have an even greater problem. The long-form census is used to guide the development of and provide population descriptors for many other surveys, including those undertaken by the private sector. Other data sources are often linked to the census to provide further context. A voluntary survey will not be usable for these purposes. As a consequence, Statistics Canada will almost certainly lose its reputation as the "world's most respected census agency." "

If this decision is not reversed, Canada will stand alone among developed nations in not having detailed information about its population. The Harper government will appear to have made a decision based on ideology rather than evidence. Worse yet, it has imposed an uninformed approach to public policy on all other levels of government, health authorities and institutions. The Harper government will have signalled that it is no longer committed to accountability.

\section{Marsha Cohen MD MHSc}

Associate Editor, Research

Paul C. Hébert MD MHSc

Editor-in-Chief

CMAJ

With the editorial advisory team members,

Ken Flegel MDCM MSc and Noni MacDonald MD MSc

Competing interests: See www.cmaj.ca/misc/edboard.shtml.

\section{CMAJ 2010. DOI:10.1503/cmaj.100976}

\section{REFERENCES}

1. 2011 Census questionnaire. Ottawa (ON): Statistics Canada; 2010. Available: www12.statcan.gc.ca/census-recensement/2011/ref/gazette-eng.cfm (accessed 2010 July 12).

2. 2006 Census technical report: coverage. Ottawa (ON): Statistics Canada; 2010 Available: www12.statcan.gc.ca/census-recensement/2006/ref/rp-guides/rp/coverage -couverture/cov-couv_index-eng.cfm (accessed 2010 July 12).

3. The CSIS Act: Warning note [section 21, subsection 3]. Ottawa (ON): Canadian Security Intelligence Service; 2004. Available: www.csis-scrs.gc.ca/pblctns/ct /cssct-eng.asp (accessed 2010 July 12)

4. Burns KE, Duffett M, Kuo ME, et al. A guide for the design and conduct of selfadministered surveys of clinicians. CMAJ 2008;179:245-52.

5. Siddiqui H. Gutting of census stirs opposition to Stephen Harper. Toronto Star 2010; July 10 . 